\title{
Postharvest quality of essential oil treated $\operatorname{roses}^{(1)}$
}

\author{
GUILHERME MARIANO MANFREDINI(2); PATRÍCIA DUARTE DE OLIVEIRA PAIVA(2); \\ ELKA FABIANA APARECIDA ALMEIDA(3); ÂNGELA MARIA PEREIRA DO NASCIMENTO(2); \\ THAÍS SILVA SALES ${ }^{(4)}$; LEANDRA OLIVEIRA SANTOS(5)
}

\begin{abstract}
The loss of commercial quality during storage and transportation of roses is one of the factors that reflect on production costs, leading producers to preventively apply harmful chemicals, mainly to hamper Botrytis cinerea development and reduce further losses. An alternative to increase flower longevity without contaminating the environment with harmful chemicals is the use of natural products, such as essential oils, which have fungistatic and insecticide properties, as well as low toxicity. The objective of this study was to evaluate the effect of essential oils on the vase life of Rosa cv. Avalanche: 12 treatments were tested, resulting from the combination of 5 types of essential oils plus the control in two cold storage periods ( 2 to 6 days) at $1{ }^{\circ} \mathrm{C}, 90-95 \% \mathrm{RH}$. The essential oils tested were eucalyptus, cinnamon, lemongrass and peppermint (1\%), clove (0.1\%), plus a control with distilled water. Application was made by spraying the flower buds. After storage at low temperatures, the flower stems were kept in a room (16 ${ }^{\circ} \mathrm{C}, 70 \% \mathrm{RH}$ ) during 10 days for evaluation. Flower stems stored for 2 days in a cold chamber showed better means for darkening, turgor and bent neck, as well as a lower weight loss by the stems. The application of lemongrass essential oil at $1 \%$ caused burns on the petals, compromising quality and pot life. The essential oils of peppermint and eucalyptus allowed flower quality maintenance until the 10th day of evaluation. It is possible to conclude that post-harvest spraying with peppermint or eucalyptus essential oil at $1 \%$, combined with cold storage for 2 days, provided greater longevity and quality for $\mathrm{cv}$. Avalanche roses.
\end{abstract}

Keywords: Rosa sp., alternative control, cold storage, natural products,

\section{RESUMO}

Qualidade pós-colheita de rosas tratadas com óleos essenciais

A perda da qualidade comercial de rosas durante o armazenamento pós-colheita e transporte é um dos fatores que mais oneram o custo de produção e leva os produtores a realizar a aplicação preventiva de produtos químicos nocivos, principalmente para evitar o aparecimento de lesões do fungo Botrytis cinerea. Uma das alternativas para aumentar a durabilidade das flores de forma ecologicamente correta é a utilização de produtos naturais, como os óleos essenciais, que apresentam características fungistáticas e inseticidas, além de baixa toxicidade. O objetivo deste trabalho foi avaliar o efeito da aplicação em pós-colheita de diferentes óleos essenciais na durabilidade de hastes de Rosa cv. Avalanche em 2 períodos de armazenamento em câmara fria. Foram testados 12 tratamentos resultantes da combinação de 5 tipos de óleos essenciais mais a testemunha associados à dois períodos de armazenamento refrigerado, 2 e 6 dias, sob $1{ }^{\circ} \mathrm{C}$ e $90-95 \%$ UR. Foram testados óleos essenciais de: eucalipto, canela, capimlimão e hortelã-pimenta (a 1\%), cravo-da-índia (a 0,1\%), e a testemunha, com água destilada. A aplicação foi feita por meio da pulverização nos botões florais. Após o armazenamento refrigerado, as hastes florais foram mantidas em uma sala escura $\left(16^{\circ} \mathrm{C}\right.$, $70 \%$ UR) por dez dias para avaliação. As hastes armazenadas por 2 dias em câmara fria apresentaram as melhores médias para as notas de escurecimento, turgescência e tombamento do pedúnculo, assim como uma menor perda de peso das hastes. A aplicação de óleo essencial de capim-limão a $1 \%$ provocou fitotoxidade, indicada pela queima nas pétalas, comprometendo a qualidade e vida de vaso. Os óleos essenciais de hortelã-pimenta e eucalipto favoreceram a manutenção da qualidade das flores até o décimo dia de avaliação. Conclui-se que a pulverização pós-colheita com óleo essencial de hortelã-pimenta ou eucalipto a $1 \%$ e o armazenamento em câmara fria por 2 dias possibilitam maior durabilidade e qualidade de rosas Avalanche.

Palavras-chave: Rosa sp., controle alternativo, armazenamento refrigerado, produtos naturais,

\section{INTRODUCTION}

Essential oils are volatile compounds produced in different plant parts, widely used as fragrances in perfumes, aromatherapy and in the food industry; their application is still restricted in other purposes, such as flower postharvest (ISMAN, 2000).

Essential oils play different roles when applied to plants: resistance to pests and diseases due to their fungistatic and insecticide properties, as well as low toxicity. In order to

DOI: http://dx.doi.org/10.14295/oh.v23i2.993

(1) Received in 24/11/2016 and accepted in 31/05/2017

(2) Universidade Federal de Lavras (UFLA), Departamento de Agricultura, Lavras-MG, Brazil

(3) Universidade Federal de Minas Gerais (UFMG), Instituto de Ciências Agrárias, Montes Claros-MG, Brazil. *Corresponding author: elkaflori@ hotmail.com

(4) Universidade Federal do Vale do Jequitinhonha e Mucuri (UFVJM), Departamento de Agricultura, Diamantina-MG, Brazil

${ }^{(5)}$ Empresa de Pesquisa Agropecuária de Minas Gerais (EPAMIG), Nova Porteirinha-MG, Brazil

Licensed by CC BY 4.0 
reduce the use of pesticides in agriculture, the interest in the possibility of applying essential oils for the control of pathogens has increased (DAFERRERA et al., 2000).

The terpene-hydrocarbon complex, as well as their oxygenated derivatives, such as aldehydes, ketones, acids and esters, are responsible for the various effects produced by essential oils (SARTORI et al., 2011). These compounds have been used as post-harvest protective agents due to their action as antagonists (WISNIEWSKI et al., 2001). In roses, the effect of lemongrass, rosemary, horsetail, chamomile and basil oils has been observed in the protection against high numbers of pathogens, as well as evaluations of ginger and mint oils (SARTORI et al., 2011).

One of the factors affecting the commercial quality of cut flowers is the incidence of fungi, mainly Botrytis cinerea, common in both planting and post-harvest storage and transport (ELAD, 1998). The infestation of this fungus can shorten the shelf life of several products, causing large losses (TRIPATHI et al., 2008). A higher fungal incidence is common during storage and transport, due to ethylene production, predisposing the flowers to infection. The use of products that inhibit ethylene production also reduces the incidence of Botrytis cinerea (ELAD et al., 2014).

Another factor that affects the longevity of cut flowers is temperature, and this is one of the most important means for the preservation of flower stems, along with other factors such as available water, moisture and ethylene action. The reduction in post-harvest temperature extends the storage period and, consequently, the pot life of flowers (DIAS et al., 2005). The parameters turgescence, darkening and bent neck are very important in the quality evaluation of flower stems. Turgescence is necessary for the development of flower buds and for the continuity of the metabolic activity in the cut flower (HASTENREITER et al., 2006). Darkening may be related to water stress or low carbohydrate concentration (REID, 2002) and bent neck probably occurs due to the presence of bacteria that block xylem vessels and hinder water flow (WITTE and DOORN, 1988), common processes in the senescence of cut flowers.

Studies on the application of essential oils to cut flowers associated with cold storage are still scarce, with a record of the unsuccessful use of rosemary oil and ginger oil in roses after harvest (BASTOS et al., 2016). Therefore, the objective of this study was to evaluate the effect of different essential oils on the post-harvest longevity of Rosa cv. Avalanche, in two cold storage periods.

\section{MATERIAL AND METHODS}

Rosa cv. Avalanche flower stems produced in a protected environment of a commercial crop without any pre- or post-harvest treatment were harvested in the morning at commercial harvest time and standardized at $35 \mathrm{~cm}$ in length, with three pairs of leaves. The stems were placed in cardboard boxes with the base immersed in potable water and transported to the laboratory for a period of 3 hours.

The flower stems were treated with five types of essential oils plus the control, and stored in a cold chamber at $1{ }^{\circ} \mathrm{C}$ and $\mathrm{RH} 90-95 \%$ for 2 or 6 days, with the stem base immersed in water. The essential oils tested were: eucalyptus (Eucalyptus citriodora), cinnamon (Cinnamomum zeylanicum), lemongrass (Cymbopogon citratus) and peppermint (Mentha piperita), at 1\%, and clove (Syzygium aromaticum) at $0.1 \%$, sprayed on the flower stems. As a control, spraying was performed with distilled water. The essential oils $\left(\mathrm{LASZLO}^{\circledR}\right)$ were diluted in distilled water and $0.01 \%$ Tween $20\left(\right.$ SIGMA-ALDRICH $\left.^{\circledR}\right)$, and the $\mathrm{pH}$ of the solution was adjusted to 7.0. The flower stems were then placed in $2 \mathrm{~L}$-plastic pots containing $500 \mathrm{~mL}$ of potable water and covered with transparent plastic film. The height of the water slide in the container was $8 \mathrm{~cm}$.

After the storage period, the flower stems were kept in water and transferred to a laboratory room at a temperature of $16{ }^{\circ} \mathrm{C}$ and $70 \% \mathrm{RH}$ (room temperature), remaining in these conditions for 10 days. Stem fresh weight and visual quality were evaluated every two days, water absorption was analyzed daily and sugar content was also determined. The fresh weight was evaluated by weighing the flower stems, and visual quality (darkening and turgescence of the petals, and peduncle angle), using the criteria established by Pietro et al. (2012), according to Table 1. Water absorption was evaluated by measurements of the actual volume in the plastic container in which the roses were held. In addition to these parameters, the total sugar content of rose petals was determined using the Anthrone Method (DISCHE, 1962).

Table 1. Rating for visual analysis of Rosa cv. Avalanche

\begin{tabular}{|c|c|c|c|c|}
\hline Characteristics & Rate 4 & Rate 3 & Rate 2 & Rate 1 \\
\hline Petal darkening & No darker petals & $\begin{array}{c}5 \text { to } 19 \% \text { of darker } \\
\text { petals }\end{array}$ & 20 to $29 \%$ of darker petals & $\begin{array}{c}\text { More than } 30 \% \text { of darker } \\
\text { petals }\end{array}$ \\
\hline Petal turgescence & Petals fully turgid & $\begin{array}{l}\text { Slightly withered } \\
\text { petals }\end{array}$ & Withered petals & Petals fully turgid \\
\hline Angle of stalk & Upright flower & $\begin{array}{l}\text { Angle between } 1 \text { to } \\
30^{\circ}\end{array}$ & Angle between 31 to $90^{\circ}$ & $\begin{array}{l}\text { Angle greater than } \\
90^{\circ}\end{array}$ \\
\hline
\end{tabular}


A completely randomized design (CRD) was used, in a factorial arrangement consisting of five essential oils and distilled water and 2 storage periods in a cold chamber. The plots were subdivided in time, counting with 6 evaluation dates. Two flower stems were used per plot, with 4 replicates. Data were analyzed using the SISVAR program (FERREIRA, 2011).

\section{RESULTS AND DISCUSSION}

It was observed that no significant interaction occurred, but the differences were observed separately among the studied factors. Stems stored at $1{ }^{\circ} \mathrm{C}$ for 2 days had, after removal from the cold chamber, a high water absorption in the first two days at room temperature, followed by the reduction in water consumption, under the conditions in which they were maintained (Figure 1).

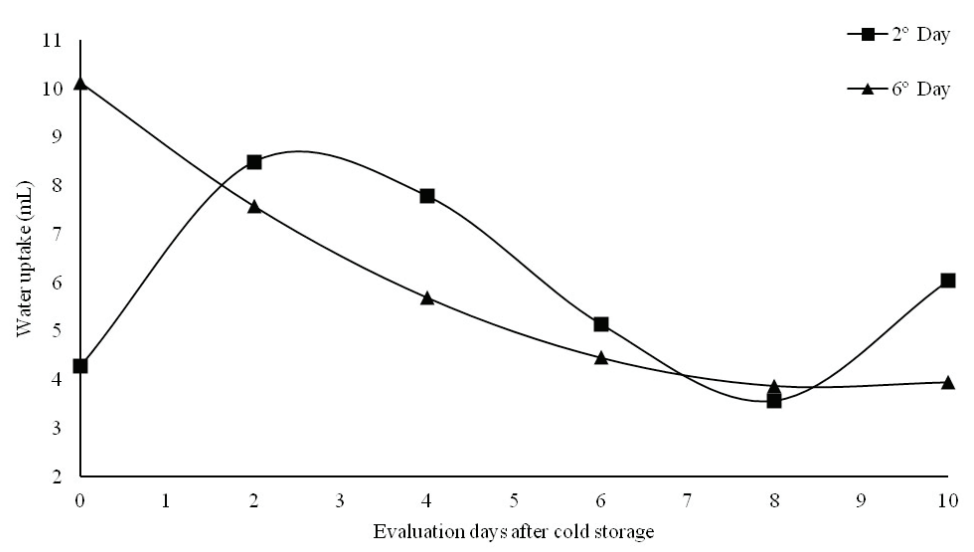

Figure 1. Water uptake in flower stems of roses cv. Avalanche treated with essential oils after storage for 2 and 6 days at $1{ }^{\circ} \mathrm{C}, 90-95 \% \mathrm{RH}$, and maintained at $16{ }^{\circ} \mathrm{C}, 70 \% \mathrm{RH}$ for up to 10 days.

With the short shelf life at low temperatures, cold slows senescence and tissue deterioration due to reduced metabolism, thus decreasing respiration and, consequently, water absorption (CELIKEL and REID, 2005). With the removal of flower stems from the cold chamber, it is possible to infer that there was a resumption of respiration rate, which favors the increase in water absorption in the first days, and subsequent stabilization.

Stems stored for 6 days at $1{ }^{\circ} \mathrm{C}$ showed a reduction in water consumption when maintained at $16{ }^{\circ} \mathrm{C}$, possibly due to the long storage period in water, which may have favored the proliferation of microorganisms that block absorption and may have caused changes in conductive vessels. Water absorption is frequently impeded by obstructions caused by microorganisms and/or the formation of tylose and gels in conducting vessels (REID and JIANG, 2012).

For the variable fresh weight, weight loss was similarly observed for the two storage periods tested (Figure 2). The decrease in fresh weight is due to the water loss by leaf stomata, besides the consumption of reserves (TORRE and FJELD, 2001). It can be inferred that the treatments used did not influence the loss of fresh weight during the evaluations at room temperature.

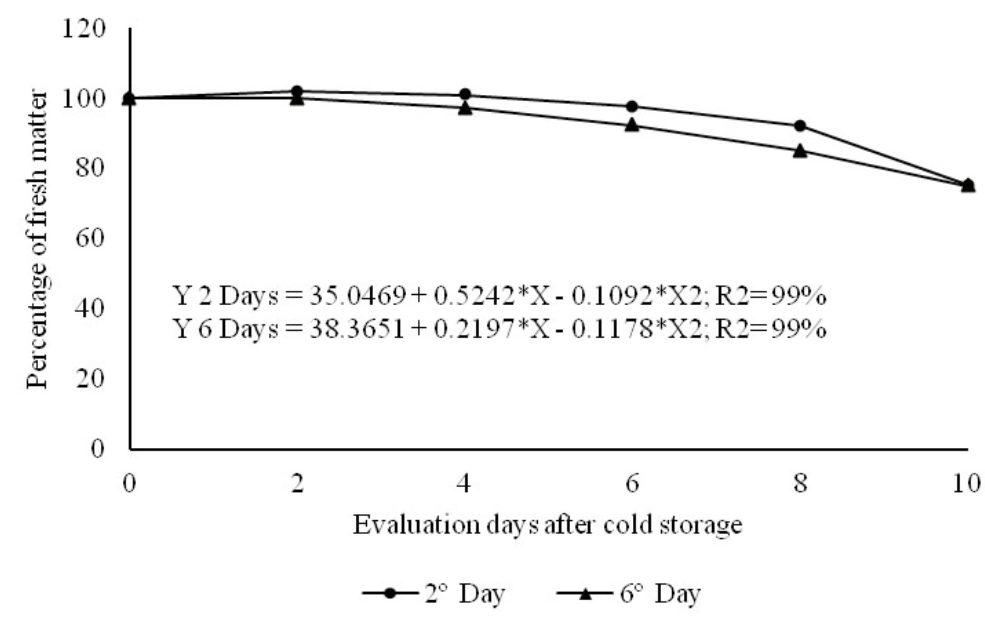

Figure 2. Fresh mass of floral stems of roses cv. Avalanche treated with essential oils after storage for 2 and 6 days at $1{ }^{\circ} \mathrm{C}, 90-95 \% \mathrm{RH}$, and maintained at $16{ }^{\circ} \mathrm{C}, 70 \% \mathrm{RH}$ for up to 10 days 
Flower stems stored for 2 days at $1{ }^{\circ} \mathrm{C}$ remained more turgid, compared to those maintained for 6 days at the same temperature (Figure 3). Plants maintained in cold chambers for long periods show an increase in ethylene production rates, as well as increased membrane permeability, leading to flower senescence (FARAGHER et al., 1984). Similar results were observed in calla lily inflorescences removed from the cold chamber at $4{ }^{\circ} \mathrm{C}$ after 10 days of storage (ALMEIDA et al., 2008).

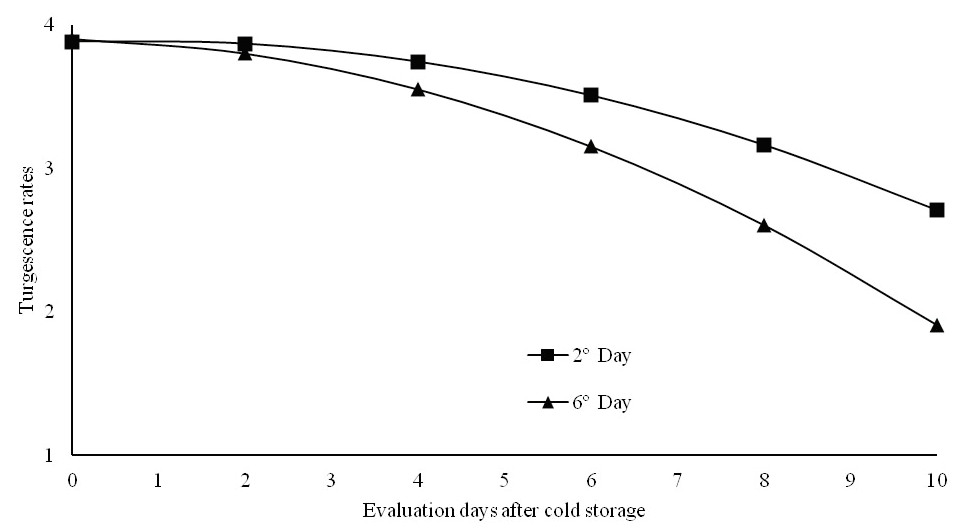

Figure 3. Notes attributed to the turgescence of stems of roses cv. Avalanche treated with essential oils after storage for 2 and 6 days at $1{ }^{\circ} \mathrm{C}, 90-95 \% \mathrm{RH}$, and maintained at $16^{\circ} \mathrm{C}, 70 \% \mathrm{RH}$, for up to 10 days.

It was verified that, for turgescence, the treatment quality of flower stems during the evaluation period with lemongrass was not efficient in maintaining the (Table 2).

Table 2. Notes attributed to the turgescence of roses stems cv. Avalanche treated with essential oils after storage for 2 and 6 days at $1{ }^{\circ} \mathrm{C}, 90-95 \% \mathrm{RH}$, and maintained at $16^{\circ} \mathrm{C}, 70 \% \mathrm{RH}$ for up to 10 days.

\begin{tabular}{|c|c|c|c|c|c|c|}
\hline Days & Water & Lemongrass & Clove & Cinnamon & Peppermint & Eucalyptus \\
\hline 0 & $4,00^{\mathrm{aA}}$ & $3,63^{\mathrm{aA}}$ & $4,00^{\mathrm{aA}}$ & $3,88^{\mathrm{aA}}$ & $4,00^{\mathrm{aA}}$ & $4,00^{\mathrm{aA}}$ \\
\hline 2 & $4,00^{\mathrm{aA}}$ & $3,25^{\mathrm{abB}}$ & $3,94^{\mathrm{aA}}$ & $3,69^{\mathrm{abB}}$ & $4,00^{\mathrm{aA}}$ & $3,81^{\mathrm{aA}}$ \\
\hline 4 & $3,81^{\mathrm{abA}}$ & $3,00^{\mathrm{bB}}$ & $3,94^{\mathrm{aA}}$ & $3,69^{\mathrm{abA}}$ & $4,00^{\mathrm{aA}}$ & $3,81^{\mathrm{aA}}$ \\
\hline 6 & $3,50^{\mathrm{bA}}$ & $2,50^{\mathrm{cB}}$ & $3,38^{\mathrm{bA}}$ & $3,44^{\mathrm{bA}}$ & $3,50^{\mathrm{bA}}$ & $3,38^{\mathrm{bA}}$ \\
\hline 8 & $3,06^{\mathrm{cAB}}$ & $1,94^{\mathrm{dC}}$ & $3,00^{\mathrm{bAB}}$ & $2,81^{\mathrm{cB}}$ & $3,50^{\mathrm{bA}}$ & $3,25^{\mathrm{bAB}}$ \\
\hline 10 & $2,56^{\mathrm{dAB}}$ & $1,50^{\mathrm{CC}}$ & $2,56^{\mathrm{cAB}}$ & $2,06^{\mathrm{dB}}$ & $2,75^{\mathrm{cA}}$ & $2,31^{\mathrm{cAB}}$ \\
\hline
\end{tabular}

Averages followed by the same lowercase letter in the column and by the same capital letter in the row do not differ from each other by the Tukey test at $5 \%$ probability.

Spraying with this essential oil caused wilting in the flowers, since removal from the cold chamber, which intensified during subsequent evaluations. This result may be due to the high concentration of citral in lemongrass, about 70-85\% (BASSOLÉ et al., 2011), which caused burning on the petals that received this treatment. Citral is a mixture of isomers with an aroma characteristic of lemon in which its fungicidal action stands out, among its biological properties. The phytotoxicity of plant extracts is a factor to be considered since, in agreement with the results obtained with roses in this study, Brum et al. (2014) and Perini et al.
(2011) also observed quality loss in watermelon and bean seedlings after spraying with lemongrass at concentrations of 2 and $4 \%$.

The scoring analysis revealed that treatments with peppermint, cloves, eucalyptus and water exhibited the highest flower turgidity on the 10th day after storage at $1{ }^{\circ} \mathrm{C}$ (Table 2).

An intense darkening of flower buds was observed in flowers treated with lemongrass essential oil due to the burn caused on the petals (Figure 4). For the other oils at the concentrations used, no burning was observed on the petals. 


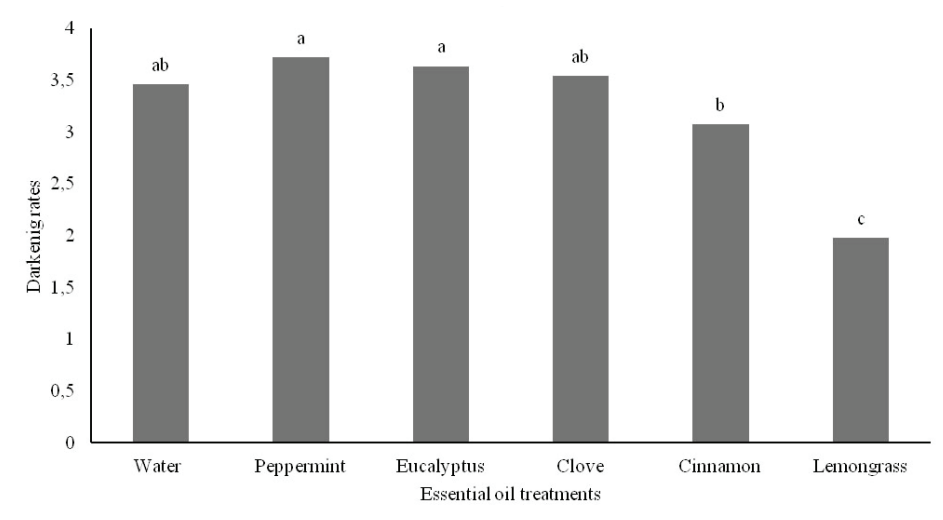

Figure 4. Evaluation by rates of the darkening of stems of roses cv. Avalanche treated with essential oils after storage for 2 and 6 days at $1{ }^{\circ} \mathrm{C}, 90-95 \% \mathrm{RH}$, and maintained at $16{ }^{\circ} \mathrm{C}, 70 \% \mathrm{RH}$ for up to 10 days. Averages followed by the same letter do not differ by Tukey test at $5 \%$ probability.

Roses stored for 6 days at $1{ }^{\circ} \mathrm{C}$ showed more intense darkening after removal from the cold chamber, compared to those stored for 2 days (Figure 5).

Stems stored at $1{ }^{\circ} \mathrm{C}$ for 6 days received lower scores for bent neck from the 8th day after removal from the cold chamber (Figure 6). This fact is probably due to a greater infection by Botrytis cinerea, since the classic symptoms observed in relation to the action of this fungus were present in the peduncle region, thus causing benting, darkening and wilting of the flower buds. The incidence of the fungus Botrytis cinerea is characterized by reddish lesions at the edges of the flowers, which are later converted into brownish colored lesions, caused by enzymatic darkening due to loss of cell compartmentalization resulting from fungal incidence (ELAD, 1988).

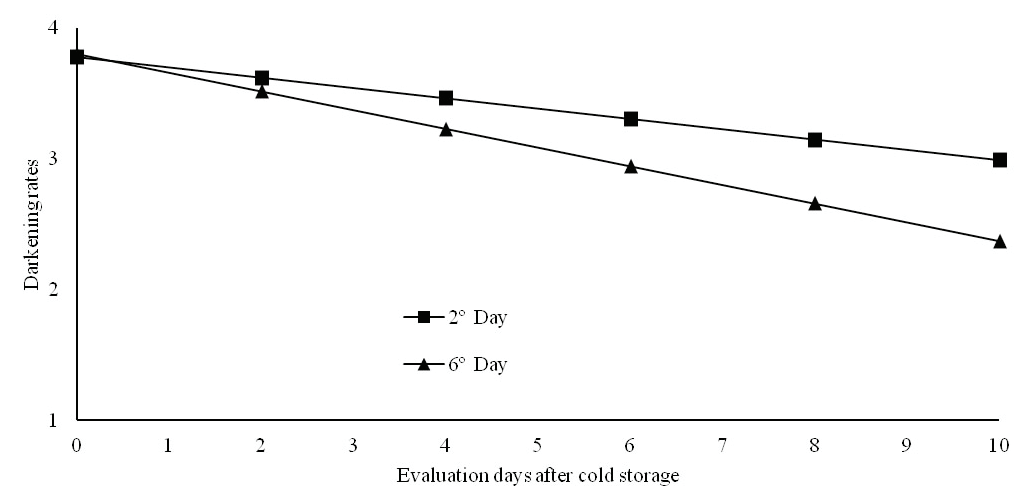

Figure 5. Rates attributed to the darkening of the stems of roses cv. Avalanche treated with essential oils after storage for 2 and 6 days at $1{ }^{\circ} \mathrm{C}, 90-95 \% \mathrm{RH}$, and maintained at $16^{\circ} \mathrm{C}, 90 \% \mathrm{RH}$ for up to 10 days. 


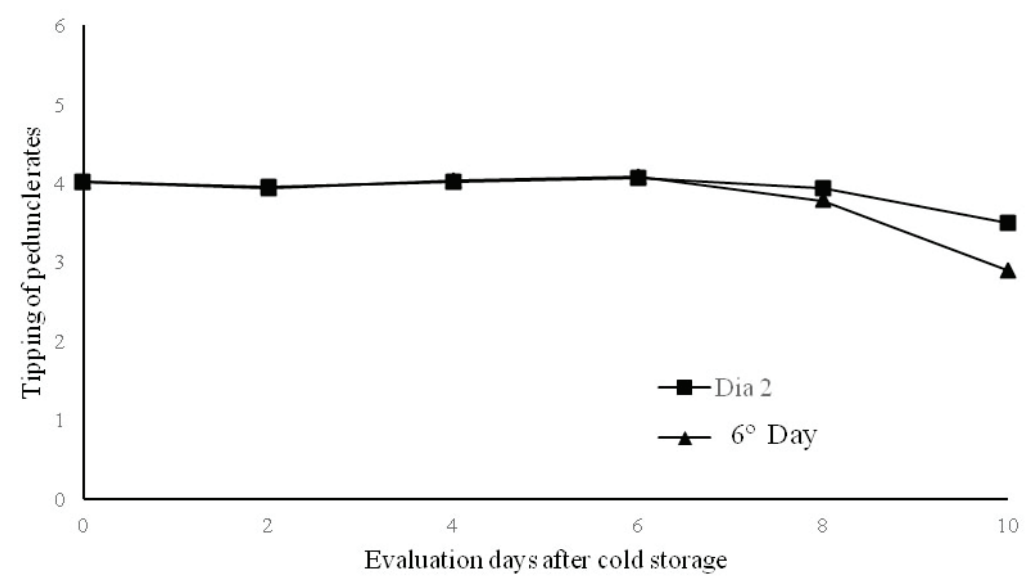

Figure 6. Rates attributed to the tipping of the peduncle of roses cv. Avalanche treated with essential oils after storage for 2 and 6 days at $1{ }^{\circ} \mathrm{C}, 90-95 \% \mathrm{RH}$, and maintained at $16{ }^{\circ} \mathrm{C}, 70 \% \mathrm{RH}$ for up to 10 days.

Flower stems stored for 6 days at $1{ }^{\circ} \mathrm{C}$ had higher contents of total sugars throughout the evaluation period, with an increase from the fourth day onwards (Figure 7). The increase in total sugar content for stems stored for 6 days may have occurred due to the increase in the content of soluble solids by dehydration, once water absorption was lower for plants stored for 6 days in a cold room.

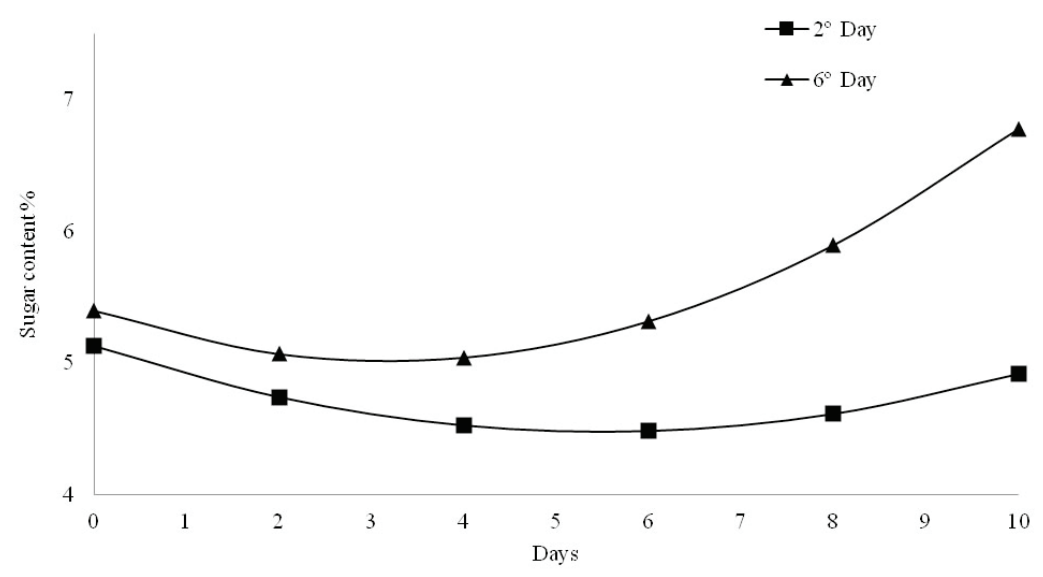

Figure 7. Total sugars content ( $\mathrm{g}$ glucose $100 \mathrm{~g}^{-1}$ ) in rose $\mathrm{cv}$. Avalanche petals treated with essential oils after storage for 2 and 6 days at $1{ }^{\circ} \mathrm{C}, 90-95 \% \mathrm{RH}$, and maintained at $16^{\circ} \mathrm{C}, 70 \% \mathrm{RH}$ for up to 10 days.

Analyzing the sugar content as a function of the treatments used (Figure 8), it was observed that stems sprayed with essential oil, with the exception of clove, showed an increase in sugar content on the last day of storage. This can be attributed to the fact that dehydration occurred, causing the concentration of soluble solids, indicating that the plants gradually lost turgescence until the last day. Thus, it can be inferred that bud wilting resulted in the accumulation of sugars on the petals. 


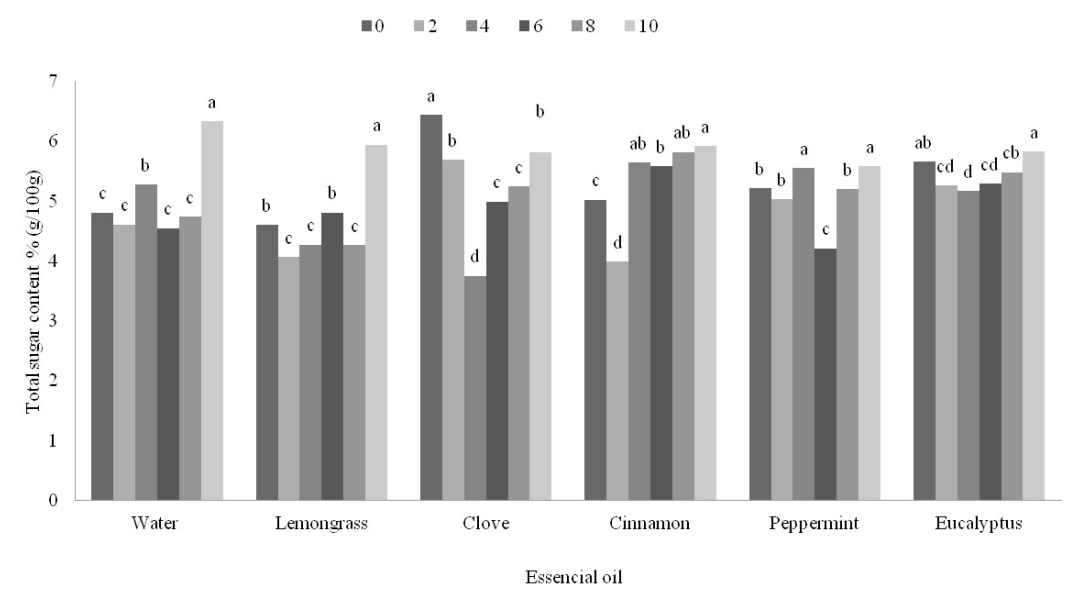

Figure 8. Total sugars content (g glucose $100 \mathrm{~g}^{-1}$ ) in rose cv. Avalanche petals treated with essential oils after storage for 2 and 6 days at $1{ }^{\circ} \mathrm{C}, 90-95 \% \mathrm{RH}$, and maintained at $16{ }^{\circ} \mathrm{C}, 70 \% \mathrm{RH}$ for up to 10 days. Averages followed by the same letter within the same treatment did not differ among themselves by the Tukey test at $5 \%$ probability.

The flower stems showed reddish lesions on the edges of the flowers, converting into brownish lesions, a characteristic symptom of the incidence of Botrytis cinerea (ELAD, 1988). Visually, it was observed that these symptoms were reduced in flower stems that received the application of eucalyptus essential oil.

Many rose producers spray chemical pesticides after harvesting the roses to extend longevity and avoid fungal incidence, especially Botrytis cinerea, which is quite common in the postharvest of this species. The results of this study corroborate those observed by other authors, that show the possibility of using natural microbial antagonists as an alternative to the products conventionally used. The application of natural substances against post-harvest pathogens contributes to the reduction in the indiscriminate use of these potentially toxic chemical pesticides (WISNIEWSKI et al., 2001).

\section{CONCLUSIONS}

Roses stored for 2 days at $1{ }^{\circ} \mathrm{C}$ have higher quality than those stored for 6 days, after 10 days of evaluation.

The lemongrass essential oil at $1 \%$ causes burns on the petals, compromising quality and pot life.

Spraying with peppermint and eucalyptus on stems of Avalanche rose cultivar favors the maintenance of flower quality until the tenth day of evaluation.

\section{ACKNOWLEDGEMENTS}

The authors would like to thank FAPEMIG, CNPq and CAPES for the grants provided and project assistance. They are also grateful to group Reijers, for the supply of flower stems.

\section{AUTHORS CONTRIBUTIONS}

G.M.M. Assembling, conduction and evaluation of the experiment in the laboratory; tabulation and statistical analysis; writing of the manuscript. P.D.O.P. Assembling; contribution to writing the manuscript. E.F.A.A. Assembling, conduction and evaluation of the experiment in the laboratory; writing of the manuscript. A.M.P.N. Assembling, conduction and evaluation of the experiment in the laboratory. T.S.S. Assembling, conduction and evaluation of the experiment in the laboratory. L.O.S. Assembling, conduction and evaluation of the experiment in the laboratory.

\section{REFERENCES}

ALMEIDA, E.F.A.; PAIVA, P.D.O.; LIMA, L.C.O.; RESENDE, M.L.F.; TAVARES, T.S. Pós-colheita de copode-leite: efeito de diferentes conservantes comerciais e armazenamento a frio. Ciência e Agrotecnologia, v.32, n.4, p.1189-1194, 2008. DOI: 10.1590/S141370542008000400023

BASSOLÉ, I.H.N.; LAMIEN-MEDA, A.; BAYALA, B.; OBAME, L.C.; ILBOUDO, A.J.; FRANZ, C.; NOVAK, J.; NEBIÉ, R.C.; DICKO, M.H. Chemical composition and antimicrobial activity of Cymbopogon citratus and Cymbopogon giganteus essential oils alone and in combination. Phytomedicine, v.18, n.12, p.1070-1074, 2011. DOI:10.1016/j.phymed.2011.05.009

BASTOS, F.E.A.; STANGER, M.C.; ALLEBRANDT, R.; STEFFENS, C.A.; KRETZSCHMAR, A.A.; RUFATO, L. Conservação de rosas 'Carola' utilizando substâncias com potencial biocida. Ornamental Horticulture, v.22, n.1, p.107-113, 2016. DOI: 10.14295/oh.v22i1.806 
BRUM, R.B.C.S.; CASTRO, H.G.; GAMA, F.R.; CARDON, C.H.; SANTOS, G.R. Phytotoxicity of essential oils in watermelon, bean and rice plants. Journal of Biotechnology and Biodiversity, v.5, n.2, p.101-109, 2014.

CELIKEL, F.G.; REID, M.S. Temperature and postharvest performance of rose (Rosa hybrid L. 'First Red') and gypsophila (Gypsophila paniculata L. 'Bristol Fairy') flowers. Acta Horticulturae, v.682, p.1789-1794, 2005. DOI: 10.17660/ActaHortic.2005.682.239

DAFERRERA, D.J.; ZIOGAS, B.N.; POLISSIOU, M.G. GC-MS analysis of essential oils from some Greek aromatic plants and their fungitoxicity on Penicillium digitatum. Journal of Agricultural and Food Chemistry, v.48, n.6, p.2576-2581, 2000. DOI: 10.1021/jf990835x

DIAS, G.M.T; FINGER, F.L.; BARBOSA, J.G. Fisiologia pós-colheita de flores de corte. Revista Brasileira de Horticultura Ornamental, v.11, n.2, p.89-99, 2005. DOI: 10.14295/rbho.v11i2.48

DISCHE, Z. Color reactions of carbohydrates. Methods in Carbohydrate Chemistry, New York: Academic Press, 1962. 475-514p.

ELAD, Y. Latent infection of Botrytis cinerea in rose flowers and combined chemical and physiological control of the disease. Crop Protection, v.7, n.6, p.361-366, 1988. DOI: $10.1016 / 0261-2194(88) 90003-8$

ELAD, Y.; ISRAELI,L.; FOGEL, M.; DAVID,D.R.; KENIGSBUCH, D.; CHALUPOWICZ, D.; MAURER, D.; LICHTER, A.; SILVEMAN, D.; BITON, S.; YITZHAK, S.; HARARI, D.; MADUEL, A.; PIVONIA, S.; ADLER, U. Conditions influencing the development of sweet basil grey mould and cultural measures for disease management. Crop Protection, v.64, p.67-77, 2014. DOI: 10.1016/j. cropro.2014.06.006

FARAGHER, J.D.; MAYAK, S.; TIROSH, T.; HALEVY, A.H. Cold storage of rose flowers: effects of cold storage and water loss on opening and vase life of 'Mercedes' roses. Scientia Horticulturae, v.24, n.3, p.369-378, 1984. DOI: 10.1016/0304-4238(84)90122-5

FERREIRA, D. F. Sisvar: a computer statistical analysis system. Ciência e Agrotecnologia, v.35, n.6, p.1039-1042, 2011. DOI: 10.1590/S1413-70542011000600001

HASTENREITER, F. A.; VIEIRA, J. G. Z.; FARIA, R. T. Longevidade pós-colheita de flores de Oncidium varicosum (Orchidaceae). Semina: Ciências Agrárias, v.27, n.1, p.2734, 2006. DOI: 10.5433/1679-0359.2006v27n1p27
ISMAN, M. B. Plant essential oils for pest and disease management. Crop protection, v.19, n.8, p.603-608, 2000. DOI: 10.1016/S0261-2194(00)00079-X

PIETRO, J. D.; MATTIUZ, B-H; MATTIUZ, C.F.M.; RODRIGUES, T.J.D. Qualidade de rosas de corte tratadas com produtos naturais. Ciência Rural, v.42, n.10, p.17811788, 2012. DOI: 10.1590/S0103-84782012005000071

PERINI, V.B.M.; CASTRO, H.G.; SANTOS, G.R.; AGUIAR, R.W.S.; LEÃO, E.U.; SEIXAS, P.T. Avaliação do efeito curativo e preventivo do óleo essencial do capim citronela no controle de Pyricularia grisea. Journal of Biotechnology and Biodiversity, v.2, n.2, p.23-27, 2011.

REID, M. S. Postharvest handling systems: ornamental crops. In: KADER, A.A. Postharvest technology of horticultural crops. Davis: University of California, 2002. p.315-326.

REID, M. S.; JIANG C. Postharvest biology and technology of cut flowers and potted plants. Horticultural Reviews, v.40, p.1-54, 2012.

SARTORI, V. C.; MAGRINI,F.E.; CRIPPA, L.B.; MARCHETT, C.; VENTURINI, L.; SILVA-RIVEIRO, R.T. Avaliação in vitro de extratos vegetais para o controle de fungos patogênicos de flores. Revista Brasileira de Agroecologia, v.6, n.2, p.117-122, 2011.

TORRE, S.; FJELD, T. Water loss and postharvest characteristics of cut roses grown at high or moderate relative air humidity. Scientia Horticulturae, v.89, n.3, p.217-226, 2001. DOI: 10.1016/S0304-4238(00)00229-6

TRIPATHI, P.; DUBEY, N. K.; SHUKLA, A. K. Use of some essential oils as post-harvest botanical fungicides in the management of grey mould of grapes caused by Botrytis cinerea. World Journal of Microbiology and Biotechnology, v.24, n.1, p.39-46, 2008. DOI: 10.1007/ s11274-007-9435-2

WISNIEWSKI, M.; WILSON, C.; EL GHAOUTH, A.; DROBY, S. Non-chemical approaches to postharvest disease control. Acta Horticulturae, v.553, p.407-412, 2001. DOI: 10.17660/ActaHortic.2001.553.93

WITTE, Y. D.; VAN DOORN, W. G. Identification of bacteria in the vase water of roses, and the effect and the effect isolated strains on water uptake. Scientia Horticulturae, v.35, n.3/4, p.285-291, 1988. DOI: 10.1016/0304-4238(88)90122-7 